\title{
Comparison of Fine-Needle Aspiration Biopsy and Postoperative Histopathologic Results in Thyroid Nodules and Evaluation of Frozen Section
}

\author{
Engin Ersin Şimşek ${ }^{1}$, ๑ Neşet Köksal ${ }^{2}$
}

${ }^{1}$ Department of Family Medicine, University of Health Sciences Istanbul Dr. Lutfi Kirdar Kartal Training and Research Hospital, Istanbul, Turkey

${ }^{2}$ Department of General Surgery, Istanbul Yeditepe University Hospital, Istanbul, Turkey

\begin{abstract}
Introduction: Thyroid nodules present serious problems, and mostly they do not carry neoplastic characteristics. Thus, they do not need to be surgically treated. Fine-needle aspiration biopsy (FNAB) is the most important diagnostic tool in the assessment of thyroid nodules and the prevention of unnecessary surgery. In this study, FNAB results of the patients operated for thyroid nodules were compared with postoperative histopathology results and the results of the frozen section were evaluated.

Methods: In this study, 206 patients who underwent preoperative FNAB for solitary thyroid nodules and multinodular goiter in the $2^{\text {nd }}$ General Surgery Department of Istanbul Haydarpaşa Numune Training and Research Hospital between 1999 and 2003 years were included. Thyroid Disease Form and pathology reports were used to evaluate the patient files retrospectively. Results: The study population ( $n=206)$ consisted of 170 (82.52\%) female and $36(17.48 \%)$ male patients and the median age of the population was 46,56 . When FNAB and histopathological examination results of the nodules were compared, four of 179 cases evaluated as benign lesions in FNAB were reported as thyroid cancer (2.23\%) as a result of histopathological examination of the surgical specimen. Nine (69.24 \%) of 13 cases as evaluated as atypical/suspicious, and all of the seven cases (100\%) reported to be malignant in FNAB were reported as thyroid cancer after histopathological examination. The relationship between FNAB and histopathological results was statistically significant in all groups $(p<0.0002)$.

Discussion and Conclusion: It was concluded that FNAB is a useful method in the evaluation of thyroid nodules, and will prevent many unnecessary operations as a cheap and reliable diagnostic tool that can be used in the selection candidates for surgery and preoperative diagnosis of thyroid carcinomas. It was also evaluated that the frozen section may be useful in guiding the operation of patients in whom FNAB cytology is considered as atypical/suspicious.

Keywords: Fine-needle aspiration biopsy; frozen section; nodule; thyroid.
\end{abstract}

T hyroid nodules continue to be a problem that closely concerns both patients and physicians, presents difficulties and triggers debates related to its diagnosis and treatment. Many diagnostic methods have been proposed to differentiate benign nodules from malignant lesions. Within the last 20 years, fine-needle aspiration biopsy
(FNAB), new radionuclide agents and sensitive ultrasonography have been widely used in the diagnosis of thyroid nodules ${ }^{[1,2]}$.

In the evaluation of thyroid nodules detected by physical examination and ultrasonography, FNAB should be preferred priorly because of the low cost and the most accurate

Correspondence (İletişim): Engin Ersin Simsek, M.D. Saglik Bilimleri Universitesi Istanbul Dr. Lutfi Kirdar Kartal Egitim ve Arastirma Hastanesi, Aile Hekimligi Anabilim Dali, Istanbul, Turkey

Phone (Telefon): +90 2164413900 - 72150 E-mail (E-posta): drersin71@gmail.com

Submitted Date (Başvuru Tarihi): 18.02.2019 Accepted Date (Kabul Tarihi): 08.01.2020

Copyright 2020 Haydarpaşa Numune Medical Journal

OPEN ACCESS This is an open access article under the CC BY-NC license (http://creativecommons.org/licenses/by-nc/4.0/) 
results ${ }^{[3]}$. With the use of FNAB, thyroid cancer can be diagnosed with high sensitivity and specificity and unnecessary surgical operations can be prevented by its routine use ${ }^{[4-6]}$. The FNAB method was first described by Martin and Ellis in $1930^{[7]}$. The accuracy of the cytological analysis with this method varies between $50-97 \%$ according to the biopsy and the experience of the cytopathology expert ${ }^{[8,9]}$. In this study, we compared FNAB results with histopathology results after surgery and evaluated the results in patients with a frozen section.

\section{Materials and Methods}

In this study, 206 patients who underwent preoperative FNAB for solitary thyroid nodules and multinodular goiter in the $2^{\text {nd }}$ General Surgery Department of Istanbul Haydarpaşa Numune Training and Research Hospital Clinic between January 1999 and December 2003 were included in the study. Patients with recurrent goiter were excluded from the study. In this study, we benefited from Thyroid Diseases Registration Form of $2^{\text {nd }}$ General Surgery Clinic in $\mathrm{HNEAH}$, where the results of thyroid function tests, size and location of nodules as specified in thyroid ultrasonography reports, FNAB results, thyroidectomy exploration findings, frozen section and pathology results were recorded.

While all patients reported having atypical/suspicious follicular and malignant lesions as a result of FNAB underwent surgical treatment, surgery was also performed for patients with benign/malignant thyroid nodules larger than $3 \mathrm{~cm}$, multinodular goiter and suspect malignancies detected on thyroid ultrasonography.

Since FNAB had to be performed in two different nodules in 17 patients, the results of a total of 223 FNABs were evaluated. In addition, FNAB procedures were repeated for the second time in 29 patients because of insufficient material for diagnosis. As a result, sufficient material for cytological interpretation could be obtained from all 223 nodules of 206 patients who were included in the evaluation. The FNAB results were evaluated by modifying the diagnostic categories reported by Lawrence and Kaplan ${ }^{[10]}$ as follows: inadequate, benign, atypical/suspicious, follicular lesion and malignant.

Patients whose FNAB results were reported as atypical/ suspicious, follicular lesion, and those whose FNAB results were reported as benign lesions, but more dominant or suspicious nodules were detected during surgery also underwent frozen section biopsies results In addition, frozen section was requested for lymph nodes whose FNAB results were reported as malignant or which might be con- sidered as pathological during exploration concerning future metastases.

Results of the FNAB and frozen section were compared with histopathology results and sensitivity, specificity, positive and negative predictive values were calculated. SPSS statistical program was used for statistical evaluation. Chisquare $(x 2)$ test was used to compare the data, and $p<0.05$ values were considered to be significant.

\section{Results}

The study population $(n=206)$ consisted of $170(82.52 \%)$ female and $36(17.48 \%)$ male patients with a male/female ratio of $1 / 4.72$. The median age of the population was 46.56 (1382 years), while the median ages of male and female patients were 50.5 and 45.7 years, respectively. Figure 1 shows the graphical distribution of cases by age and gender.

Thyroid ultrasonography revealed solitary nodules in 69 , and multiple nodules in 137 cases (Table 1). The ultrasonographic findings were consistent with the exploration findings. The results of cytological evaluations of FNAB specimens of the patients are shown in Table 2. When FNAB and histopathological examination results of the nodules were compared, four of 179 cases evaluated as benign lesions in FNAB were reported as thyroid cancer (2.23\%) as a result of histopatho-

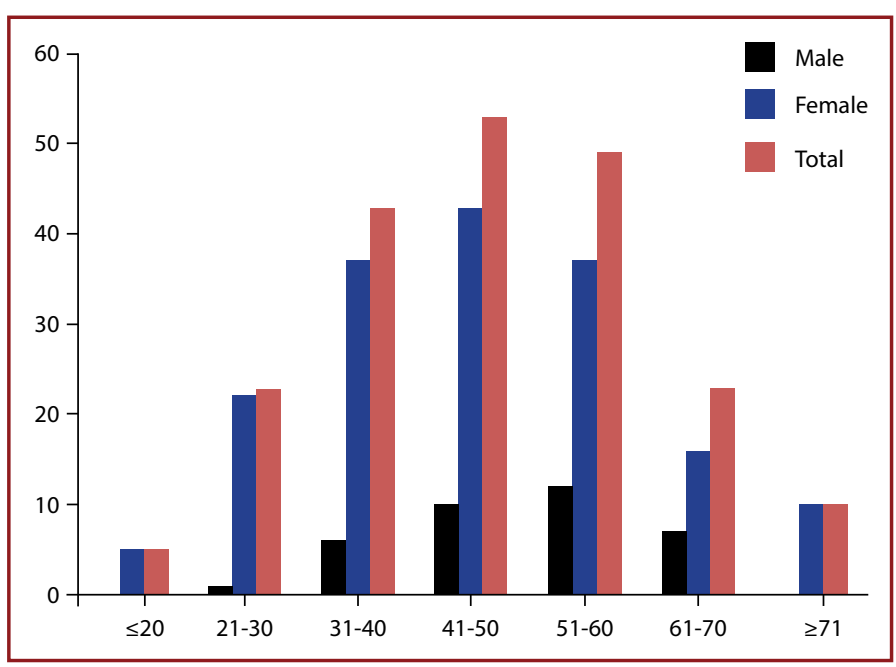

Figure 1. Distribution of the cases according to age and gender.

Table 1. Distribution of the solitary and multiple nodules in ultrasonographic examination

\begin{tabular}{|c|c|c|c|c|c|c|}
\hline \multirow[t]{2}{*}{ Gender } & \multicolumn{2}{|c|}{ Male } & \multicolumn{2}{|c|}{ Female } & \multicolumn{2}{|c|}{ Total } \\
\hline & $n$ & $\%$ & $\mathbf{n}$ & $\%$ & $\mathbf{n}$ & $\%$ \\
\hline Solitary nodule & 12 & 33.33 & 57 & 33.53 & 69 & 33.50 \\
\hline Multiple nodule & 24 & 66.67 & 113 & 66.47 & 137 & 66.50 \\
\hline Total & 36 & 100.00 & 170 & 100.00 & 206 & 100.00 \\
\hline
\end{tabular}


logical examination of the surgical specimen. Nine $(69.24 \%)$ of the 13 cases as evaluated as atypical/ suspicious, and all of the seven cases (100\%) reported to be malignant in FNAB were reported as thyroid cancer after the histopathological examination (Table 3).

The relationship between FNAB and histopathological results was statistically significant in all groups $(p<0.0002)$, ie, there was a strong correlation between histopathological results of FNAB and surgical spec.mens. P-values are given below the tables (degrees of freedom $=4$ ) (Table 4). The sensitivity and specificity of FNAB for malignancy were calculated for total, solitary and multinodular goiters (Table 5).

Frozen section results of 31 cases indicated as benign in histopathological examination of FNAB specimens were reported as benign in $30(96.77 \%)$, and thyroid cancer one case (3.23\%) as thyroid cancer, while 6 (42.85\%) of 14 cases of follicular lesion in FNAB were revealed to be follicular neoplasia after frozen section, while these lesions could not be differentiated as malign and benign.

The etiologies of patients who underwent frozen section are seen in Table 6 and the results of FNAB, frozen section and histopathological examination are shown in Table 7. The relationship between histopathological results of FNAB and frozen section specimens was statistically significant in all groups ( $p<10-5)$, ie, there was a strong correlation between histopathological results of FNAB, frozen section specimens.

\section{Discussion}

The incidence of thyroid nodules is reported to be $3-7 \%$ for the adult population, with approximately $5-15 \%$ of them having malignant properties ${ }^{[11,12]}$. In our study, the rate of malignancy in patients with FNAB was $11.16 \%$.

Thyroid carcinomas are more frequently encountered in women than in men. Thyroid cancer was detected in 21 $(91.3 \%)$ women, and two men than in $\operatorname{men}^{[13,14]}$. In the present study, 21 (91.3\%) cases with thyroid cancer were male, two were male (8.7\%), and the male/female ratio was
Table 2. FNAB results

\begin{tabular}{lcc}
\hline Cytology & $\mathbf{n}$ & $\%$ \\
\hline Benign & 179 & 80.27 \\
Atypical/Suspicious & 13 & 5.83 \\
Malignant & 7 & 3.14 \\
Follicular lesion & 24 & 10.76 \\
Total & 223 & 100.00 \\
\hline
\end{tabular}

Table 3. Cytological, and histopathological results of the FNAB specimens retrieved from 223 nodules

\begin{tabular}{|c|c|c|}
\hline FNAB & Histopathology & $\mathbf{n}$ \\
\hline \multirow[t]{10}{*}{ Benign $(n=179)$} & Multinodular Colloidal. & 121 \\
\hline & Adenomatous Hyperplasia & \\
\hline & Col. Ad. Nodule & 31 \\
\hline & Lymphocytic Thyroiditis & 5 \\
\hline & Diffuse Colloidal Hyperplasia & 5 \\
\hline & Hashimoto Thyroiditis & 1 \\
\hline & Follicular Adenoma & 10 \\
\hline & Hurthle Cell Follicular Adenoma & 1 \\
\hline & Cellular Adenomatoid Nodule & 1 \\
\hline & Papillary Ca & 4 \\
\hline \multirow[t]{9}{*}{ Follicular Lesion $(n=24)$} & Multinodular Colloidal. & 6 \\
\hline & Adenomatous Hyperplasia & \\
\hline & Col. Ad. Nodule & 3 \\
\hline & Lymphocytic Thyroiditis & 2 \\
\hline & Follicular Adenom & 5 \\
\hline & Hurthle Cell Follicular Adenoma & 3 \\
\hline & Cellular Adenomatoid Nodule & 2 \\
\hline & Hurthle Cell Carcinoma & 2 \\
\hline & Follicular Carcinoma & 1 \\
\hline \multirow[t]{4}{*}{ Atypical/Suspicious $(n=13)$} & Col. Ad. Nodule & 2 \\
\hline & Follicular Adenoma & 2 \\
\hline & Papillary Ca & 6 \\
\hline & Medullary Ca & 3 \\
\hline \multirow[t]{3}{*}{ Malignant $(n=7)$} & Papillary Ca & 5 \\
\hline & Medullary Ca & 1 \\
\hline & Malignant Lymphoma & 1 \\
\hline
\end{tabular}

Table 4. Statistical correlation between histopathological examination results of the FNAB, and surgical specimens

\begin{tabular}{|c|c|c|c|c|c|c|c|}
\hline \multirow[t]{2}{*}{ FNAB } & \multicolumn{5}{|c|}{ Histopathology } & \multirow[t]{2}{*}{ Total } & \\
\hline & $\mathbf{n}$ & $\%$ & $\mathbf{n}$ & & $\%$ & & \\
\hline Benign & 175 & 97,76 & 4 & & 2,24 & 179 & $x^{2}=94.17$ \\
\hline Follicular lesion & 21 & 87,5 & 3 & & 12,50 & 24 & $\mathrm{p}<0.0002$ \\
\hline Atypical/Suspicious & 4 & 30,76 & 9 & & 69,24 & 13 & \\
\hline
\end{tabular}


Table 5. Reliability of the FNAB

\begin{tabular}{lccc}
\hline & $\begin{array}{c}\text { Solitary } \\
\text { Nodule }\end{array}$ & $\begin{array}{c}\text { Multinodular } \\
\text { Goiter }\end{array}$ & Overall \\
\hline Sensitivity (\%) & 71.43 & 61.54 & 65.96 \\
Specificity (\%) & 87.50 & 94.53 & 92.61 \\
Accuracy of the test (\%) & 82.61 & 88.96 & 87.00 \\
Negative predictive value (\%) & 87.50 & 92.37 & 91.06 \\
Positive predictive value (\%) & 71.43 & 69.57 & 70.45 \\
False negativity (\%) & 12.50 & 7.63 & 8.94 \\
False positivity (\%) & 28.57 & 30.43 & 29.55 \\
\hline
\end{tabular}

Table 6. The reasons for requesting frozen section in 60 patients

\begin{tabular}{lcc} 
The Reasons for Requesting Frozen Section & $\mathbf{n}$ & $\%$ \\
\hline $\begin{array}{l}\text { Patients whose FNAB results were reported } \\
\text { as atypical/suspicious }\end{array}$ & 9 & 15,00 \\
$\begin{array}{l}\text { Patients whose FNAB results were reported } \\
\text { as follicular lesion }\end{array}$ & 14 & 23,33 \\
$\begin{array}{l}\text { Patients whose FNAB results were reported } \\
\text { as benign, but who were found to have more } \\
\text { dominant and suspicious nodules during } \\
\text { surgery being different from that was made }\end{array}$ & 31 & 51,66 \\
$\begin{array}{l}\text { FNAB preoperatively } \\
\text { Patients who have malignancy previously and } \\
\text { determination of pathological lymph nodes } \\
\text { which might be suspicious for metastatic }\end{array}$ & 6 & 10.00 \\
thyroid lesion during surgery & & \\
$\begin{array}{l}\text { Total } \\
\text { otal }\end{array}$ & 60 & 100.00
\end{tabular}

1/10.5. Papillary and follicular thyroid carcinomas constitute $75-80 \%$ of malignancies, and papillary cancers are often under 40 years of age and follicular cancers over 30-35 years of age ${ }^{[13]}$. In our study, the mean age of patients with thyroid carcinoma was 51.3.

In the literature, the rate of malignancy in solitary nodules is reported to be higher than in multinodular goiters ${ }^{[15,}$ 16]. According to Brawn, this rate is $15-25 \%$ in solitary nodules and between 1-6\% in multinodular ones. According to Abu-Nema, the rate of malignancy in solitary nodules varies between $2-28 \%{ }^{[16]}$. In our study, 12 (17.4\%) cancer patients were detected in 69 patients with solitary nodules, and 11 (8\%) cancer were detected in 137 multinodular patients, and these rates were consistent with the literature. FNAB, which is a fast and cost-effective method to evaluate thyroid nodules preoperatively, is widely recognized as a valuable method in distinguishing neoplastic nodules from non-neoplastic patients and in identifying patients in need of thyroid surgery and is recommended as the first diagnostic diagnostic test to evaluate thyroid nodules ${ }^{[10,17]}$.

FNAB, which has become a routine method in the evaluation of thyroid nodules and has become a diagnostic method for increasing rates, has brought about some controversy due to the lack of a specific standard in the cytological classification of aspirated material and different definitions and classifications have been reported. In our study, evaluations were made according to the modified

Table 7. Overall evaluation of FNAB, frozen section and histopathology results of patients who underwent frozen section

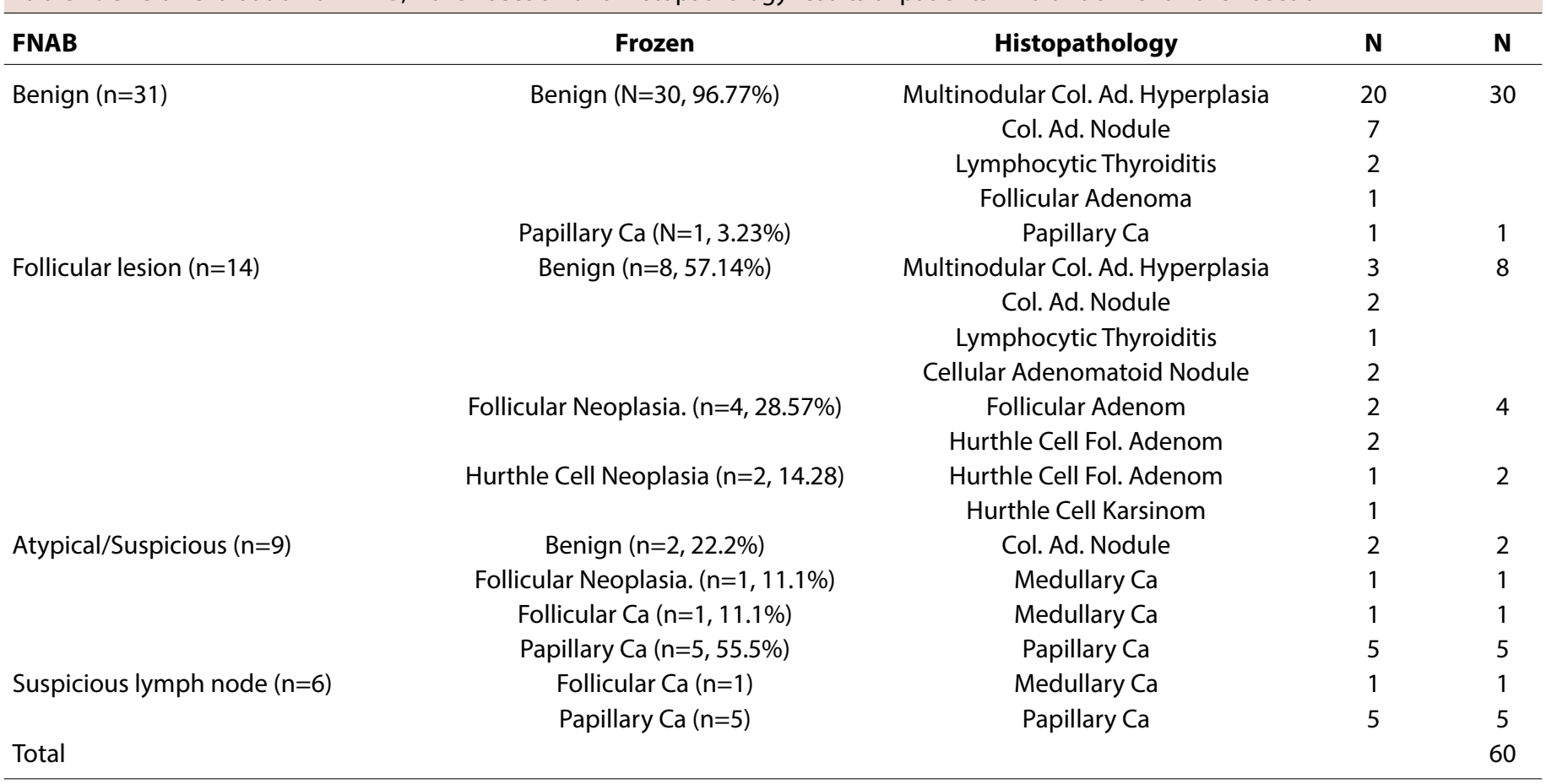


form of diagnostic categories reported by Lawrence and Kaplan ${ }^{[10]}$ used by the Pathology Clinic at the time of the study. Especially in papillary thyroid cancers, a high rate of diagnosis can be made using FNAB. In these cases, the diagnosis of FNAB is very important in determining the surgical strategy. In our study, papillary carcinoma, medullary carcinoma and malignant lymphoma were detected in five of seven patients with malignancy as FNAB. However, no matter which classification system is used, the main problem in the implementation of FNAB is the difficulty in evaluating the suspect or intermediate group. The rate of suspected or intermediate group is between $15-30 \%$ in patients undergoing $\mathrm{FNAB}$, and the rate of malignancy varies between $10-50 \%[18]$. In our study, a total of 37 cases $(16.6 \%)$ in the intermediate group were diagnosed as atypical/suspicious and follicular lesion as a result of FNAB. These rates are consistent with the rates reported in the literature.

Follicular lesions are one of the important issues in the evaluation of FNAB. When a follicular cell is detected in aspirate, it is necessary to determine capsule and vascular invasion when deciding whether it is a follicular adenoma or follicular carcinoma. Griffin does not assess follicular neoplasia with false positive or negative results. Follicular lesions in the increase in the amount of cells in case of an increase in the recommended surgical intervention ${ }^{[19]}$.

Another obstacle in the diagnosis of FNAB is the detection of Hurthle cell, which can be found in all thyroid diseases in the aspirate. Hurthle cells with large, granular cytoplasm, nuclei with pleomorphic and prominent nucleoli cells; trabecular structure in adenomas and papillary structure in carcinomas. It is important to determine these structures in diagnosis. If Hurthle cells are predominant in a tumor or all of this is seen, Hurthle cell adenoma or carcinoma is mentioned $^{[13]}$. Düren et al. ${ }^{[20]}$, in their study of 299 thyroid adenomas, 12 (4\%) Hurthle cell adenoma and 100 of three thyroid carcinoma (3\%) have found Hurthle cell carcinoma. In our study, two $(8.7 \%)$ of the 23 thyroid cancers were found as Hurthle cell carcinoma and four (1.8\%) as Hurthle cell adenoma.

The rate of preparation with insufficient or non-cellular preparation in FNAB-treated cases varies between $7-20 \%[21]$. As a result of the initial evaluation in our series, 29 patients with FNAB were considered to be inadequate, and $13 \%$ were consistent with the rates reported in the literature. The rates related to the sensitivity, specificity and reliability of FNAB in thyroid nodules were reported to be $65-98 \%$ for sensitivity, $72-100 \%$ for specificity, $73-98 \%$ for accuracy and false negativity below $5 \%{ }^{[2]}$.
The most important difficulty encountered in FNAB is falsepositive and negative evaluations. The positive predictive value of FNAB is influenced by inadequate material, atypi$\mathrm{cal} / \mathrm{suspicious} \mathrm{and} \mathrm{positive} \mathrm{evaluation} \mathrm{of} \mathrm{follicular} \mathrm{lesions.}$ If these nodules are not included in the positive group, the false-positive results are reduced, but the procedure is not very sensitive, and the cancer cases in this group cannot be treated. On the other hand, if these nodules are considered positive, the positive predictive value decreases. Bugis et al. ${ }^{[22]}$ found that the accuracy of the test was $90 \%$ only when the cytological findings of malignancy were considered. In our study, the sensitivity of FNAB was $65.96 \%$, the specificity was $92.61 \%$, and the accuracy rate was $87 \%$. However, we believe that even if there is little doubt in cytology, cases should be operated considering the risk of malignancy. The false negative rate of $8.94 \%$ is important concerning demonstrating the recognition of a large proportion of benign nodules with FNAB. In our study, the false negative rate and the high false-positive rate can be attributed to the inadequacy of the material intake and the error in the cytopathological evaluation. Undoubtedly, the false negativity rate will decrease if the experience increases. False-positive results in thyroid nodules may increase the risk of complication associated with a wider surgical approach in the patient group reported as atypical or suspected FNAB result, whereas malinities detected after insufficient surgery may lead to later reexploration and complementary thyroidectomy. In various studies, the sensitivity of the frozen section in the thyroid nodules was reported to be $63-87 \%$, specificity rates were $95-100 \%$ and accuracy rates were reported to be between $71-98 \%[23-27]$. In Chang et al.'s ${ }^{[28]}$ study, which was conducted with the medical records of 662 patients, FNAB and frozen section in cases where incompatible with $78.9 \%$ of the frozen section in the accuracy of the FNAB reached $21.1 \%$, the positive predictive value of the frozen section with the determination of malignancy $97 \%$ and negative predictive value were reported as $95.5 \%$. In addition, the rate of diagnostic accuracy of frozen section in indeterminate or insufficient FNAB was $92.6 \%$, and indeterminate was $23 \%$ in the FNAB group. In the same study, both FNAB and frozen section did not show any false-positive results $\mathrm{n}$ our study, we found $66.6 \%$ of the frozen section with a frozen section in the atypical/ suspicious FNA group, while frozen and pleural histopathology results were consistent. Malignancy was detected in only one patient (3.23\%) in the desired group of patients with FNAB but due to exploration findings. False positivity was not observed in both patients with FNAB and frozen section. 


\section{Conclusion}

We concluded that FNAB is a useful method in the evaluation of thyroid nodules, and could prevent many unnecessary operations as a cheap and reliable diagnostic tool that can be used in the selection candidates for surgery and preoperative diagnosis of thyroid carcinomas. Intraoperative frozen section is a method to recognize the malignancy in patients with atypical/suspected diagnoses received based on histopathological examination of the FNAB specimens and to reduce the need for more extensive surgery or reoperation.

\section{Acknowledgement}

The authors thank Önder Peker, MD; Atilla Çelik, MD and Önder Altın, MD for their assistance with manuscript review and editing. Ethics Committee Approval: This study was produced from the thesis, which was performed as a file examination in Istanbul Haydarpaşa Numune Training and Research Hospital between January 1999 and December 2003, by completing the local permission procedures of Haydarpaşa Numune Training and Research Hospital as of the date of the thesis study and the retrospective structure of the study. The study was not previously published elsewhere.

Peer-review: Externally peer-reviewed.

Authorship Contributions: Concept: E.E.Ş., N.K.; Design: E.E.Ş.; Data Collection or Processing: E.E.Ş., N.K.; Analysis or Interpretation: E.E.Ş., N.K.; Literature Search: E.E.Ş., N.K.; Writing: E.E.Ş.

Conflict of, Interest: None declared.

Financial Disclosure: The authors declared that this study received no financial support.

\section{References}

1. Cochand-Priollet B, Guillausseau PJ, Chagnon S, Hoang C, Guillausseau-Scholer $C$, Chanson $P$, et al. The diagnostic value of fine-needle aspiration biopsy under ultrasonography in nonfunctional thyroid nodules: a prospective study comparing cytologic and histologic findings. Am J Med 1994;97:152-7.

2. Raber W, Kmen E, Kaserer K, WaldhäusI W, Vierhapper H. [The "cold" nodule of the thyroid gland: 20 years experience with 2,071 patients and diagnostic limits of fine needle biopsy]. [Article in German]. Wien Klin Wochenschr 1997;109:116-22.

3. American Thyroid Association (ATA) Guidelines Taskforce on Thyroid Nodules and Differentiated Thyroid Cancer, Cooper DS, Doherty GM, Haugen BR, Kloos RT, Lee SL, et al. Revised American Thyroid Association management guidelines for patients with thyroid nodules and differentiated thyroid cancer. Thyroid 2009;19:1167-214. [CrossRef]

4. Gharib H, Goellner JR, Johnson DA. Fine-needle aspiration cytology of the thyroid. A 12-year experience with 11,000 biopsies. Clin Lab Med 1993;13:699-709. [CrossRef]

5. Hambleton C, Kandil E. Appropriate and accurate diagnosis of thyroid nodules: a review of thyroid fine-needle aspiration. Int J Clin Exp Med 2013;6:413-22.

6. Ogilvie JB, Piatigorsky EJ, Clark OH. Current status of fine needle aspiration for thyroid nodules. Adv Surg 2006;40:223-38.

7. Wolters U, Krug B, Theissen P, Kurrle N. [Effectiveness of preoperative diagnosis in scintigraphically cold thyroid nodule]. [Article in German]. Chirurg 1997;68:700-4. [CrossRef]

8. Grant CS, Hay ID, Gough IR, McCarthy PM, Goellner JR. Longterm follow-up of patients with benign thyroid fine-needle aspiration cytologic diagnoses. Surgery 1989;106:980-5.

9. McHenry CR, Rosen IB, Walfish PG, Bedard Y. Influence of fineneedle aspiration biopsy and frozen section examination on the management of thyroid cancer. Am J Surg 1993;166:3536. [CrossRef]

10. Lawrence W Jr, Kaplan BJ. Diagnosis and management of patients with thyroid nodules. J Surg Oncol 2002;80:157-70.

11. Woeber KA. Cost-effective evaluation of the patient with a thyroid nodule. Surg Clin North Am 1995;75:357-63. [CrossRef]

12. Gharib H, Papini E. Thyroid nodules: clinical importance, assessment, and treatment. Endocrinol Metab Clin North Am 2007;36:707-35. [CrossRef]

13. Chen H, Zeiger MA, Clark DP, Westra WH, Udelsman R. Papillary carcinoma of the thyroid: can operative management be based solely on fine-needle aspiration? J Am Coll Surg 1997;184:605-10.

14. Marley EF, Oertel YC. Fine-needle aspiration of thyroid lesions in 57 pregnant and postpartum women. Diagn Cytopathol 1997;16:122-5. [CrossRef]

15. Dean DS, Gharib H. Epidemiology of thyroid nodules. Best Pract Res Clin Endocrinol Metab 2008;22:901-11. [CrossRef]

16. Pacini F, Fontanelli M, Fugazzola L, Elisei R, Romei C, Di Coscio $\mathrm{G}$, et al. Routine measurement of serum calcitonin in nodular thyroid diseases allows the preoperative diagnosis of unsuspected sporadic medullary thyroid carcinoma. J Clin Endocrinol Metab 1994;78:826-9. [CrossRef]

17. Rosen IB, Wallace C, Strawbridge HG, Walfish PG. Reevaluation of needle aspiration cytology in detection of thyroid cancer. Surgery 1981;90:747-56.

18. Boey J, Hsu C, Collins RJ. False-negative errors in fine-needle aspiration biopsy of dominant thyroid nodules: a prospective follow-up study. World J Surg 1986;10:623-30. [CrossRef]

19. Griffin JE. Management of thyroid nodules. Am J Med Sci 1988;296:336-47. [CrossRef]

20. Düren $E$, Ünal G, Ünal H. Hurthle hücreli tiroit adenomu ve karsinomu. Türk Tıp Dergisi 1975;11:526-30.

21. Krauss EA, Mahon M, Fede JM, Zhang L. Application of the Bethesda Classification for Thyroid Fine-Needle Aspiration: Institutional Experience and Meta-analysis. Arch Pathol Lab Med 2016;140:1121-31. [CrossRef]

22. Bugis SP, Young JE, Archibald SD, Chen VS. Diagnostic accuracy of fine-needle aspiration biopsy versus frozen section in solitary thyroid nodules. Am J Surg 1986;152:411-6. [CrossRef]

23. Duek SD, Goldenberg D, Linn S, Krausz MM, Hershko DD. The role of fine-needle aspiration and intraoperative frozen sec- 
tion in the surgical management of solitary thyroid nodules. Surg Today 2002;32:857-61. [CrossRef]

24. Abboud B, Allam S, Chacra LA, Ingea H, Tohme C, Farah P. Use of fine-needle aspiration cytology and frozen section in the management of nodular goiters. Head Neck 2003;25:32-6.

25. Lumachi F, Borsato S, Tregnaghi A, Marino F, Poletti A, lacobone $M$, et al. Accuracy of fine-needle aspiration cytology and frozen-section examination in patients with thyroid cancer. Biomed Pharmacother 2004;58:56-60. [CrossRef]

26. Cetin B, Aslan S, Hatiboglu C, Babacan B, Onder A, Celik A, et al.
Frozen section in thyroid surgery: is it a necessity? Can J Surg 2004;47:29-33.

27. Callcut RA, Selvaggi SM, Mack E, Ozgul O, Warner T, Chen H. The utility of frozen section evaluation for follicular thyroid lesions. Ann Surg Oncol 2004;11:94-8. [CrossRef]

28. Chang HY, Lin JD, Chen JF, Huang BY, Hsueh C, Jeng LB, et al. Correlation of fine needle aspiration cytology and frozen section biopsies in the diagnosis of thyroid nodules. J Clin Pathol 1997;50:1005-9. [CrossRef] 